\title{
IMPACT OF CAPITAL STRUCTURE AND FIRM FINANCIAL PERFORMANCE ON FIRM VALUE: EVIDENCE OF AGRIBUSINESS FIRMS IN INDONESIA STOCK EXCHANGE
}

\author{
Siregar Risa Yanti Diannisa, Anggraeni Lukytawati, Pranowo Koes \\ School of Business, Bogor Agricultural University, Indonesia \\ *E-mail: ichasiregar55@gmail.com
}

\begin{abstract}
Agribusiness is one of the driving sectors to national economy. This sector has high risk lead to uncertainty to capital and firms' earnings. The aim of this study is to analyze the impact of capital structure and firm financial performance to agribusiness firm value. Panel regression is used to analyze 16 sample of agribusiness companies from 2012 to 2016 . The results of this study showed that capital structure (DER) and firm financial performance (ROA \& ROE) have a positive and significant effect to agribusiness firm value. Firms must to restructure their debts to avoid the risk of bankruptcy and improve its business performance. Investors must be considering not to invest in firms with risk of bankruptcy. The government must to establish the rules more firmly and take an action against the firms that violate the rules.
\end{abstract}

\section{KEY WORDS}

Agribusiness, capital structure, firm financial performance, firm value, panel regression.

Agribusiness as one of the driver sectors to national economy has role in sufficient people needs, increase farmers' income, raw material provider, provide a business chance and employment opportunities and also support to food security. This sector has high risk characteristic that makes agribusiness firms have difficulty in business development. It leads to the uncertainty to their capital and firms' earnings.

Table 1 - Financial development of agribusiness firms at 2013-2016

\begin{tabular}{ccccc}
\hline Sector & Year & DER & ROA & ROE \\
\hline Agribusiness & 2013 & 2.33 & 3.97 & 11.81 \\
& 2014 & 1.85 & 2.94 & 1.36 \\
& 2015 & 2.28 & 2.13 & -0.47 \\
\hline Average & 2016 & 1.43 & 0.68 & -89.81 \\
\hline
\end{tabular}

Table 1 shows that financial condition of agribusiness firms at 2013-2016 have been decreasing. It because some firms have been decreasing in their sales value that cause by decreasing of global commodities prices and also decreasing of their production volume that impact decreasing in their earnings (ROA \& ROE) every year, but their DER has improve because of decreasing as result of firms can repayment their debt and market capitalization is increasing that showed in Table 2.

Table 2 - The development of agribusiness stock trading at 2012-2016

\begin{tabular}{cccc}
\hline Year & $\begin{array}{c}\text { Market Capitalization } \\
\text { (Million Rupiah) }\end{array}$ & Volume (Million) & Value (Million Rupiah) \\
\hline 2012 & 114,543 & 48,337 & $37,846,828$ \\
2013 & 135,652 & 47,635 & $37,322,918$ \\
2014 & 161,781 & 85,054 & $65,499,197$ \\
2015 & 118,308 & 102,172 & $75,824,926$ \\
2016 & 137,159 & 105,674 & $77,784,152$ \\
\hline
\end{tabular}

Indonesia stock exchange since 2016 has taken positive growth in all aspect at capital market such as market capitalization, volume and trading frequency. It also felt by all listed 
companies, including agribusiness firm, that showed in Table 2. It because improvement in macroeconomy condition and domestic demand that impact economy growth.

Capital structure and financial performance are factors that determine the height and low of firm values. Trade-off theory said that determination of optimal capital structure will minimize the cost of capital and increasing firm value, as well the financial performance that described by profitability. Signaling theory said that the highest profitability will show a good performance and prospect of the firms, so investor will respond the positive signals and the firm value will increase (Febrianti 2012).

Maximizing firm value is important and the main goal of firms, because maximizing firm value means maximizing prosperity of investors and it will show from their stock market price (Wahyudi and Pawestri 2006). If the highest stock price can describe the highest firm value, and vice versa. Firm value is interpreted as the price that investors are willing to pay if firms will be sold (Sartono 2010).

The problem about capital structure and financial performance of firms and their impact to firm value have been widely examined in Indonesia. This research has examined at firms such as banking, manufacture, mining, food and beverages, retail trade, consumer goods and also miscellaneous industry. the research on agribusiness firms is still rarely to do.

The research on capital structure and financial performance to firm value has been done by Aggarwal and Padhan (2012), (Rasyid (2015), Winarto (2015) and Paminto et al. (2016) who found that profitability has significant and positive impact to firm value. The research on capital structure impact to firm value by them found different result. Aggarwal and Padhan (2012) found that capital structure has negative and significant impact to firm value. Rasyid (2015) and Paminto et al. (2016) found that capital structure has negative and unsignificant impact to firm value, but Winarto (2015) found that capital structure has positive and significant impact to firm value.

The research on capital structure is still interesting to do, especially at agribusiness firms, because every sector has differences in determining their capital structure and also the problems of capital structure is directly related to their financial performance which is if firms can not determine their optimal capital, it will make a bad impact to firm financial performance and their firm value.

The purposes of this research are:

- To analyze the capital structure, firm financial performance and agribusiness firm value that listed in Indonesia Stock Exchange at 2012-2016;

- To analyze the impact of capital structure and firm financial performance to agribusiness firm value that listed in Indonesia Stock Exchange at 2012-2016.

\section{METHODS OF RESEARCH}

Sample and Data. The type of data that used in this research is secondary data. The data is the audited firm's financial statement at 2012-2016 and originated from IDX website. This research used 16 firms from 21 listed firms in Indonesia Stock Exchange. It determines with purposive sampling method.

Table 3 - Research Variables

\begin{tabular}{lllll}
\hline Variable & & Notation & Unit & Literature \\
\hline Dependent & Firm Value & PBV & $\%$ & Paminto et al. (2016) \\
Independent & Capital Structure & DER & $\%$ & Paminto et al. (2016) \\
& Financial Performance & ROA \& ROE & $\%$ & Paminto et al. (2016); \\
& & & & Aggarwal dan Padhan (2017) \\
Control & Dividend Policy & DPR & $\%$ & Paminto et al. (2016) \\
& Firm Size & SIZE & (In) & Aggarwal dan Padhan (2017) \\
& Firm Growth & GROWTH & $\%$ & Paminto et al. (2016) \\
\hline
\end{tabular}

This research is using descriptive approach and quantitative approach. Descriptive approach is using to answer the first purpose of this research that explain average of capital structure, firm financial performance and firm value. 
Quantitative approach is using to answer the second purpose of this research to explain the impact of capital structure and firm financial performance to agribusiness firm value and it uses data panel method. To test the effect of capital structure and firm financial performance on firm value the formulation used is:

$$
P B V_{i t}=\alpha+\beta_{1} D E R_{i t}+\beta_{2} R O A_{i t}+\beta_{3} R O E_{i t}+\beta_{4} D P R_{i t}+\beta_{5} \text { Size }_{i t}+\beta_{6} \text { Growth }_{i t}+\varepsilon_{i t}
$$

Where: $\alpha$ and $\beta$ is intercept term, $i$ is number of companies $(1,2,3 \ldots, 16), t$ is time period $(2012,2013, \ldots, 2016)$, and $\varepsilon$ is error term.

\section{RESULTS AND DISCUSSION}

The result from this descriptive analysis used to explain the characteristic of firm value (PBV), capital structure (DER) and firm financial performance (ROA \& ROE) from 16 firms that used in this research. The firm with the highest average of firm value (PBV) is PT Inti Agri Resources. At 2015, this firm has been increasing in their stock price because this firm has been taking an agreement acquisition for PT Argo Artha Surya at December $17^{\text {th }} 2015$. It makes investor respond this news with taking a trading in this firms. The lowest average of firm value is for PT Bakrie Sumatera Plantation. At 2013, this firm has been decreasing in their stock price because there was a news about this firms cannot repayment their short terms debt that makes there is negative sentiment from investor. It happens because at 2013 this sales value was declining because declining of their production volume. The result is showed in Figure 1.

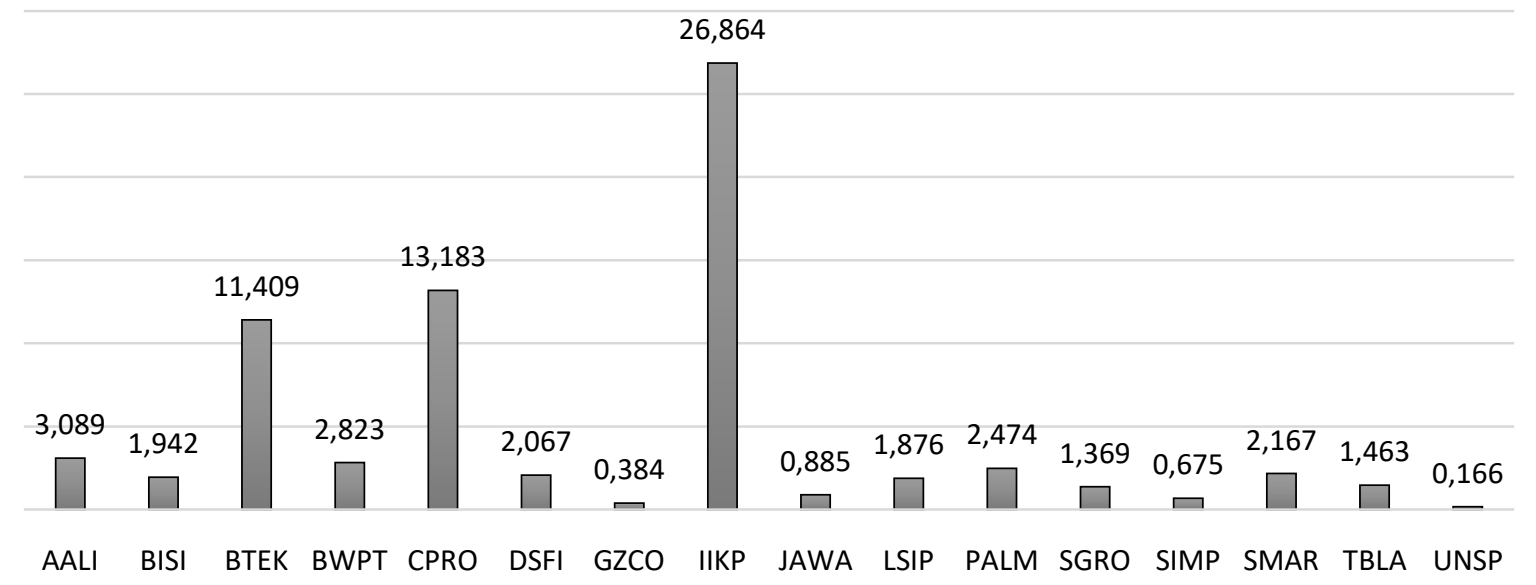

Figure 1 - Average of agribusiness firm value

Figure 2 showed that the firm with the highest average of capital structure (DER) is PT Central Proteina Prima. Government has set rules about the amount of comparison between debt and capital in Peraturan Menteri Keuangan Republik Indonesia No. 169/PMK.010/2015 that the biggest amount of comparison between debt and capital is $4: 1$. This firm has broken the rules because at 2009 until last 2012 this firm has problem about the arrear of obligation debt, the changing of business pattern at 2016, and also decreasing sales that cause the raw material was reduced. It also makes decrease in firm's earnings. The lowest average of capital structure is for PT Inti Agri Resources. It because this firm has been doing repayment of their bank debt and they can maintain their stability of debt and capital usage like government rules.

The firm with the highest average of firm financial performance (ROA) is PT Astra Agro Lestari that showed in figure 3. At 2012, this firm has the highest earnings because increasing sales volume of CPO and Kernel and also increasing of domestic demand. The lowest average of firm financial performance (ROA) is PT Gozco Plantation. At 2016, this firm 
has been decreasing on sales volume and increasing in their production cost. The total asset of firm also has been decreasing because there was amortization at plant assets and also there was decreasing on stock investment value at one of their subsidiaries.

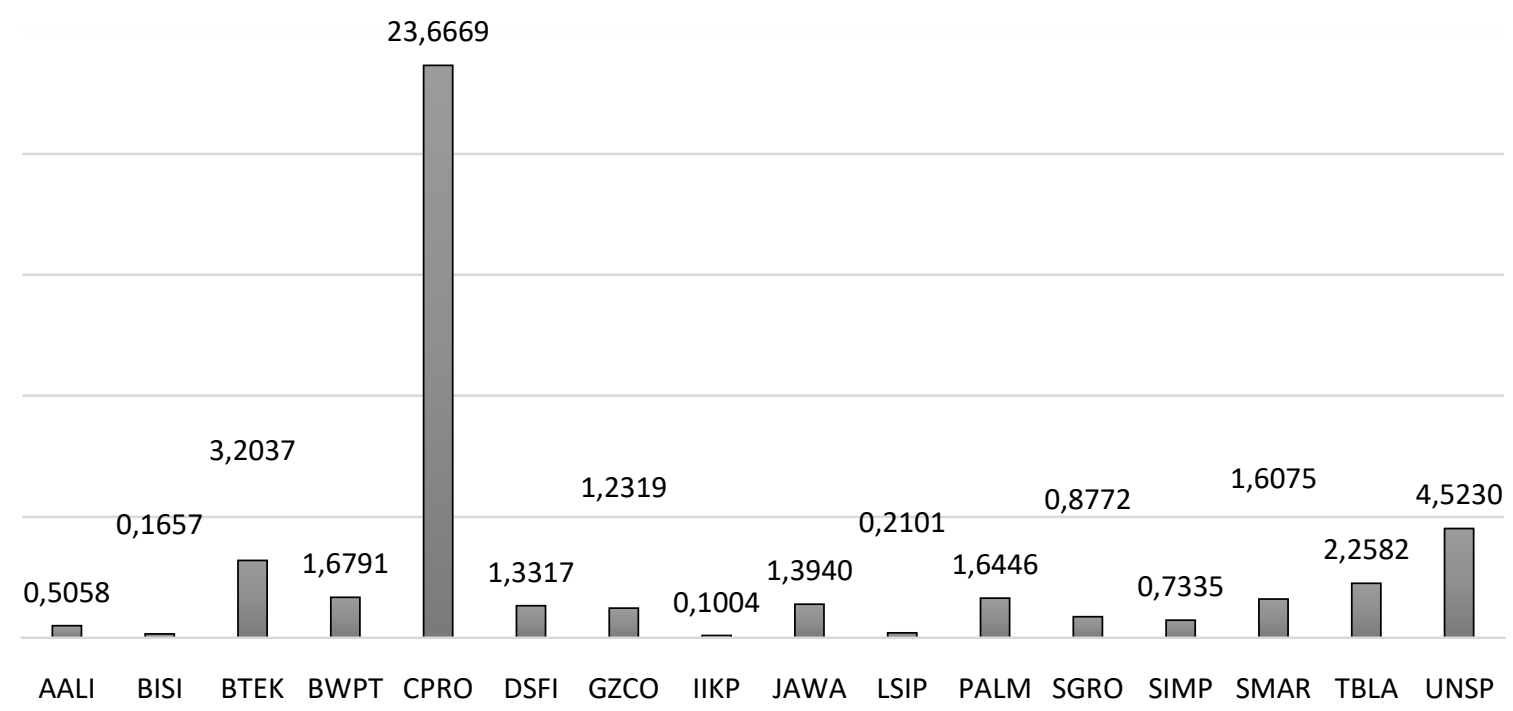

Figure 2 - Average of agribusiness capital structure

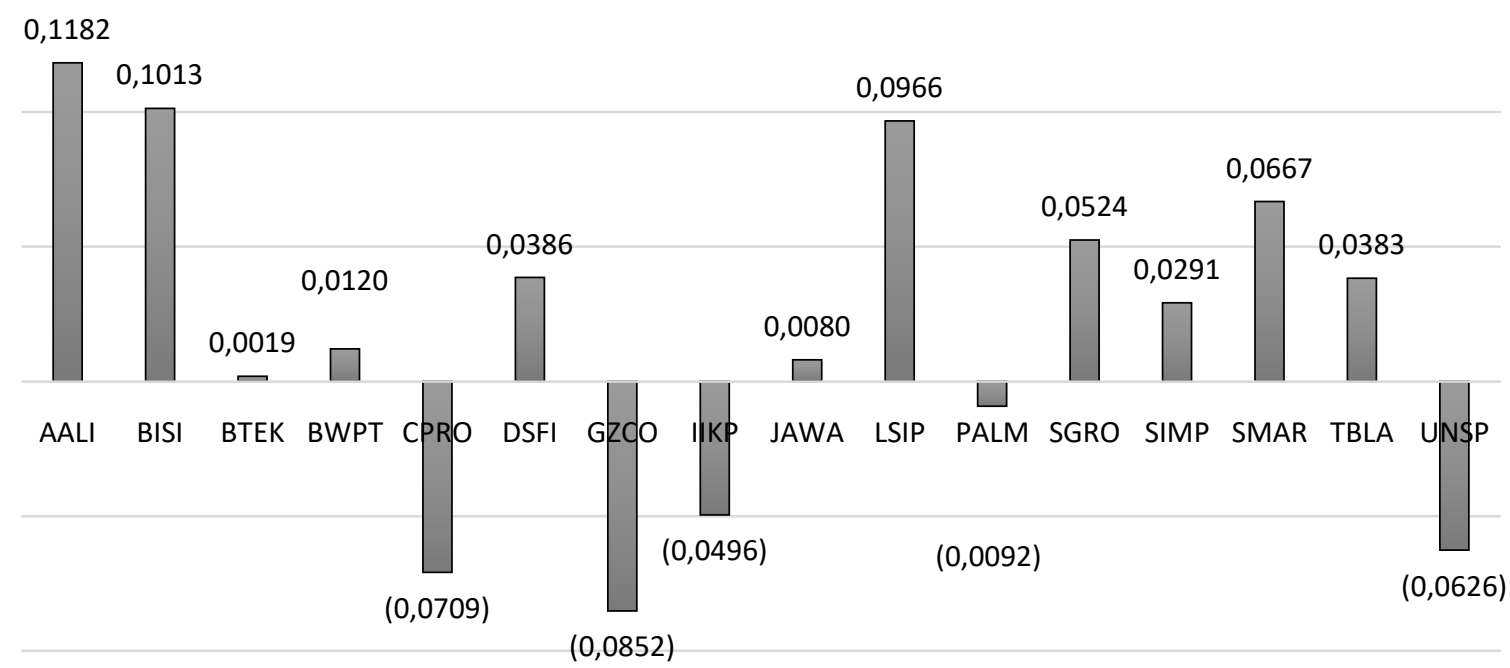

Figure 3 - Average of agribusiness firm financial performance $(\mathrm{ROA})$

Figure 4 showed that the highest average of ROE was owned by PT SMART. At 2014, this firm got the highest earnings because increasing in sales volume of CPO and Kernel and also increasing in their equity. The lowest average of ROE is PT Central Proteina Prima. Performance of firm in 2016 was the lowest because this firm has been decreasing in sales volume, change in business pattern with partner business and also increasing obligation debt and bank debt.

This research uses a panel data approach where testing for the second purpose of this study is how the influence of capital structure and financial performance on firm value in agribusiness companies. The results of the testing of the best models are obtained from the panel fixed effect model. The results of the fixed effect processing model are presented in Table 4.

Table 4 shows that the model in agribusiness companies has an R-Squared of 0.960715 which means that $96.1 \%$ of the diversity of the dependent variable (firm value / 
PBV) can be explained by independent variables (DER, ROA, ROE, DPR, SIZE \& GROWTH) in this study and the remaining $3.8 \%$ is explained by other variables outside of the model.

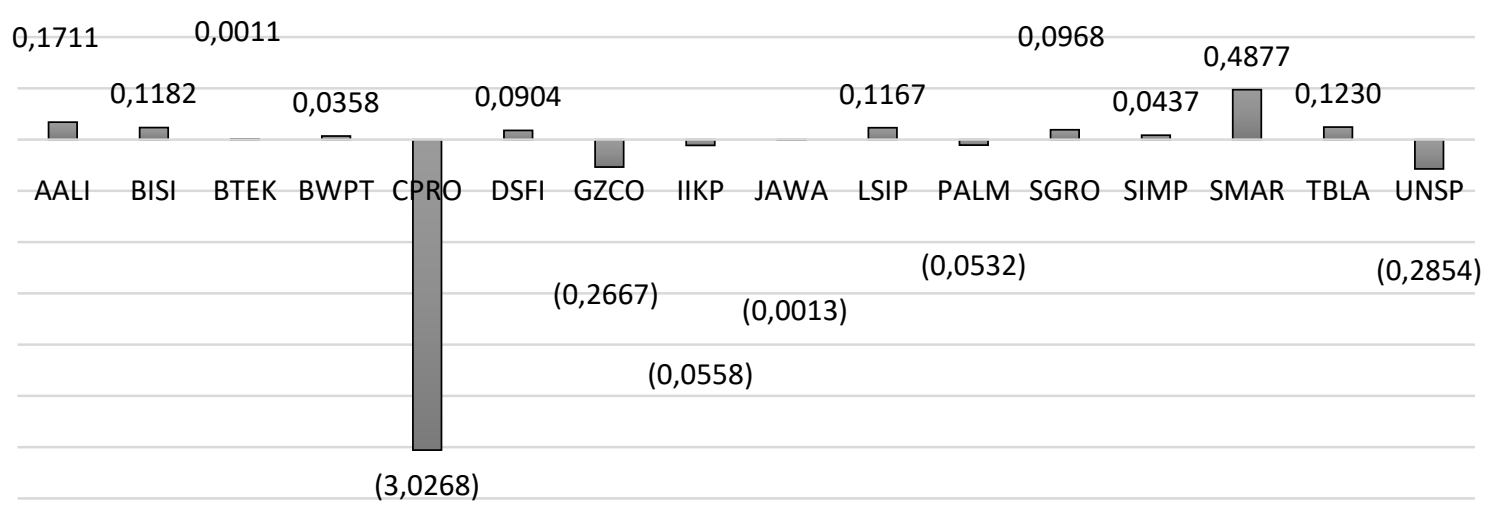

Figure 4 - Average of agribusiness firm financial (ROE)

The results of this study which states that an increase in capital structure (DER) has a significant positive effect on value. This result is in accordance with the trade-off theory and capital structure theory where the result show that the firm is able to maintain the optimal value of the capital structure it uses. This is a positive signal for investors to invest in this firm. Investors have hopes that the management of the firm is able to manage their obligations well and be a good development for the future of the firm. This result is consistent with the research of Hermuningsih (2013) and Winarto (2015) who found that the capital structure has a significant and positive effect on firm value.

Table 4 - Factors that impact agribusiness firm value

\begin{tabular}{ccccc}
\hline Variable & Coefficient & Std. Error & t-Statistic & Prob. \\
\hline C & 8.278080 & 41.63161 & 0.198841 & 0.8431 \\
DER & 0.058642 & 0.001538 & 38.13949 & 0.0000 \\
ROA & 2.547464 & 0.549098 & 4.639363 & 0.0000 \\
ROE & 0.124763 & 0.018067 & 6.905471 & 0.0000 \\
DPR & 0.032439 & 0.106716 & 0.303976 & 0.7622 \\
SIZE & 1.583928 & 1.885614 & 0.840006 & 0.4044 \\
GROWTH & -0.026329 & 0.053315 & -0.493846 & 0.6233 \\
\hline R-Squared & 0.960715 & & & \\
Prob (F-Statistik) & 0.000000 & & & \\
Durbin Watson & 2.150109 & & & \\
\hline
\end{tabular}

Signaling theory states that high profitability shows good corporate performance and prospects, so investors will respond positively to these signals and the value of the firm will increase (Febrianti 2012). The result show that Return on assets has an positive and significant effect on firm value. This theory is in accordance with the These results indicate that the higher earnings power, the more efficient asset turnover and / or the higher the profit margin that the firm will get and this will have an impact on increasing the value of the firm. This result is consistent with the research conducted by Chen and Chen (2011) and Ulupui (2005) who found that ROA had a significant positive effect on firm value.

Return on equity has an positive and significant effect on firm value. This shows the firm's ability to return their obligations, both long-term and short-term debt obligations and also obligations to shareholders in the form of dividends. If the firm achieves that, it will attract investors to buy shares in the firm. This research is in accordance with what was done by Hermuningsih (2013) who found that ROE had a significant positive effect on firm value.

Managerial Implications. A high corporate value will make investors believe in the firm's performance and future prospects. An investor needs a variety of information on the firm's financial performance to reduce the risks and conditions of uncertainty that occur. The higher 
the stock price, the higher the value of the firm and the prosperity of shareholders who invest in the firm. From that the firm continues to maintain good performance will increase the firm's stock price in order to attract investors to keep investing in the firm.

The results of this study note that there are three factors that influence firm value, namely capital structure (DER) and firm financial performance (ROA and ROE). The firm's capital structure seen from the average value is recommended to companies to use debt as their main source of funding because by increasing their debts the value of the firm will also increase, but the use must also be in accordance with the standards of government, namely the composition of debt and capital 4: 1. Agribusiness companies in this study in general in determining the amount of debt and capital were still below the threshold set by the government except PT Central Proteina Prima and PT Bakrie Sumatera Plantations. The two companies need to restructure the use of corporate debt to maintain the stability of the firm's profitability which continues to decline and maintain the stability of its firm value, because if this continues it will cause both companies to lose their investors who end up in bankruptcy risk and will be suspended and delisted by the Indonesia Stock Exchange. The two companies must also improve their business performance so that the firm's finances are immediately stabilized and the debt problems are resolved immediately.

Investors are recommended to choose companies that are able to maintain the amount of debt and capital use in accordance with the maximum set by the government and also companies that can provide high returns from both ROA and firm ROE. This study shows that the types of business activities in the field of oil palm plantations and agricultural raw material providers provide benefits for investors if they invest in these business activities. Investors need to avoid companies that are at risk of going bankrupt and not providing benefits to investors such as companies that are related to the type of business activities of fisheries.

The government as a regulator needs to take action against companies that have a large amount of debt and capital that exceeds the established threshold and the firm's performance continues to decline by issuing warnings such as stock trading suspended and delisted from the stock market. The stipulated regulations need to be tightened and provide strict sanctions to companies that violate government regulations so that companies are more careful in regulating their capital so that corporate value and financial performance can be maintained.

\section{CONCLUSION}

Based on the results of the descriptive analysis it is known that in general the average agribusiness firm experiences an increase in the value of the firm, which can be seen from the stock price offered in the market greater than the price offered by the firm. The firm's capital structure (DER) is generally seen that all companies use a conservative capital structure policy in which management uses debt as its main source of funding that can be seen from the average of all companies. Firm performance (ROA) is generally seen from the average value that the financial performance of all companies still provides benefits and is able to guarantee the assets of the firm. While for ROE in general, all companies suffer losses with a value with several companies that have very low average values and are negative.

Firm value is significantly influenced by capital structure and firm financial performance (ROA \& ROE) and all variables have a positive and significant effect, which means that any increase in capital structure and financial performance will increase the value of the firm. While the control variables of firm growth, dividend policy and firm size have no significant effect on firm value, where firm size and dividend policy have a positive effect, while firm growth has a negative effect on firm value.

\section{REFERENCES}

1. Aggarwal dan Padhan. 2017. Impact of Capital Structure on Firm Value: evidence from Indian Hospitality Industry. Theoretical Economics Letters. 7: 982-1000. 
2. Chen dan Chen. 2011. The Influence of Profitability on Firm Value with Capital Structure as the Mediator and Firm Size and Industry as Moderators. Journal of Investment Management and Financial Innovations. 8(3): 121-129.

3. Febrianti. 2012. Faktor-Faktor yang Mempengaruhi Nilai Perusahaan pada Industri Pertambangan di Bursa Efek Indonesia. Jurnal Bisnis dan Akuntansi. 14(2): 141-156.

4. Hermuningsih. 2013. Pengaruh Profitabilitas, Growth Opportunity, Struktur Modal terhadap Nilai Perusahaan pada perusahaan public di Indonesia. Buletin Ekonomi Moneter dan Perbankan. 16(2): 127-148.

5. Paminto, Setyadi, Sinaga. 2016. The Effect of Capital Structure, Firm Growth and Dividend Policy on Profitability and Firm Value of the Oil Palm Plantation Companies in Indonesia. European Journal of Business and Management. 8(33): 123-134.

6. Rasyid. 2015. Effects of Ownership Structure, Capital Structure, Profitability and Firm's Growth towards Firm Value. International Journal Business and Management Invention. 4(4): 25-31.

7. Sartono. 2010. Manajemen Keuangan Teori dan Aplikasi. Edisi ke-4. Yogyakarta (ID): BPFE.

8. Sholihah, Hidayat, Yuliati. 2014. Persepsi dan Sikap Nasabah dalam Memperoleh Kredit Usaha Agribisnis pada Bank Konvesional dan Bank Syariah. Jurnal Sosial Ekonomi Pertanian. 7(1): 24-31.

9. Ulupui. 2005. Analisis Rasio Likuiditas, Aktivitas, dan Profitabilitas terhadap Return Saham (Studi Pada Perusahaan Makanan dan Minuman dengan Kategori Industri Barang Konsumsi di BEl. Jurnal Akuntansi Ekonomi. Denpasar(ID): Universitas Udayana

10. Wahyudi dan Prawestri. 2006. Implikasi Struktur Kepemilikan terhadap Nilai Perusahaan dengan Keputusan Keuangan Sebagai Variabel Intervening. Simposium Nasional Akunansi (SNA) IX. Padang(ID).

11. Winarto. 2015. The Determinants of Manufacturer Firm Value in Indonesia Stock Exchange. International Journal of Information, Business and Management. 7(4): 323349. 